\title{
Classificação de Cargos, e suas Inovações
}

\section{A LEI N. 3.780, DE 1960}

Govêrno Federal vem, de há muito, tentando estruturar, com o propósito de atender aos interêsses da Administração e estimular os servidores, os cargos e funçôes do serviço público civil brasileiro. A mais recente e bem elabotada dessas tentativas é a Lei n. 3.780, de 12 de julho de 1960, que dispõe sôbre a classificação de cargos.

Ainda não muito bem compreendida pelo funcionalismo porque, desprezando o tempo de serviço, determinou, em seu artigo $20, \S 1 .^{\circ}$, que o enquadramento fôsse feito "passando os ocupantes dos cargos e funções, considerados em conjunto, por ordem decrescente de padrão e referência, a ocupar, ce cima para baixo, as classes indicadas", tem despertado polêmica e até mesmo ensejado diversos recursos - ainda que sem amparo legal - ao Poder ludiciário.

Inovou a Lei n. ${ }^{\circ}$ 3.780-60 o critério estabelecido para a criação, classificação e provimento das funções gratificadas, estipulando que estas deverão cbedecer aos principios de hierarquia funcional, analogia das funções, importância, vulto e complexidade das respectivas atribuiçóes, e, ainda, estabelecendo uma correlação fundamental entre as atribuições do cargo efetivo do funcionário e a função gratificada para que fôr designado.

Também o valor dessas funções sofreu fundamental alteração porque, além de ser uma resultante da avaliação dos fatôres arima aludidos, é igual à diferença entre o valor estabelecido para o simbolo respectivo e o vencimento do cargo efetivo exercido pelo funcionário.

Por outro lado, a par da clássica promoção por antiguidade ou por merecimento, estabeleceu um aumento fixo, variável de nivel para nivel, por triênio de efetivo exercicio - visando a compensar a dificuldade, nas repartições cuịos quadros de pessoal são peṇuenos e sem movimentação, de obterem os servidores aumento de vencimentos.

Alterou, fundamentalmente, o instituto da readaptação, dispondo que o funcionário que vinha exercendo, inintertuptamente e por prazo superior a dois anos, atribuições diversas das pertinentes à classe em que foi enquadrado. ou que houvesse exercido essas atribuições até 21 de agôsto de 1959, por mais de cinco anos, fôsse readaptado - sem prejuizo do direito de opção pela situação decorrente do enquadramento, e a ser exercido dentro de 180 dias da readaptação. 
Estabeleceu, para os servidores ocupantes de cargos para cujo ingresso ou desempenho seja exigida apresentação de diploma de curso superior, gratificação calculada percentualmente, conforme o tempo de duração dêsses cursos.

Implantou defintivamente o sistema do mérito, estabelecendo que serão preenchidas por concurso de provas e titulos as vagas da classe inicial ou única para cujo provimento não se tenha estabelecido o regime de acesso, e a metade das vagas das classes compreendidas nesse regime.

Moralizou o provimento das vagas em caráter interino, estabelecendo - prazo máximo de um ano para essa forma de ocupação de cargo.

Estabeleceu o sistema de provas práticas que compreendam tarefas tipicas relativas ao exercicio do novo cargo, para o acesso, o qual, no sistema anterior, nada mais era do que uma promoção por antiguidade.

Ctiou uma Comissão de Classificação de Cargos, funcionando junto ao D. A. S. P., composta de cinco membros, nomeados pelo Presidente da República e escolhidos entre funcionários com mais de dez anos de serviço público federal e reconhecida experiência em assuntos administrativos ou juridıcos - à qual compete regulamentar a Lei $n .^{\circ} 3.780-60$, examinar as reclamações e recursos que se suscitarem e velar pela observância e pela aplicação dos preceitos nela estatuidos.

Previtu, ainda, para os servidores que exerçam atividades técnico-cientificas, de magistério ou pesquisas, a opção pelo regime de tempo integral, estabelecendo uma gratificação calculada percentualmente, para êsse grupo.

Sendo uma lei que estabeleceu um sistema de classificação de cargos, alterou fundamentalmente o tradicional escalonamento das carreiras e séries functonais existentes, elevando os niveis de algumas enquanto que outras eram conservadas quase que na situação salarial anterior - o que nem sempre tem sido entendido por velhos servidores, que se julgam prejudicados pe'o novo sistema, que considerou apenas, deveres e atribuições para o estabelecimento da retribuição de cada cargo, e o vencimento para a colocação do funcionátio no nivel correspondente do cargo em que fôt enquadrado.

Não é, de fato, perfeita, a Lei n. 3.780, de 1960, mas representa um grande passo - um passo de gigante, aliás - no caminho da perfeição de nosso sistema estrutural de cargos e carteiras.

Resta, agora, à Comissão de Classificiçcão de Cargos terminada a tarefa hercúlea de enquadrar os cargos e funçôes do serviço público civil brasileiro e estabelecer tôda a regulamentação necessária ao cumprimento das demais disposições nela estabelecidas, aperfeiçoá-la e escoimá-la dos senões naturais a qualquer trabalho dêsse vulto.

Não será demais recordar que nos Estados Unidos - padrão em questões de administração de pessoal - a classificação dos cargos de ser serviço civil foi objeto de diversas alterações, por leis sucessivas, até atingir o atual estágio. 